\title{
Ruins of Empire: Decolonial Queer Ecologies in Cliff's No Telephone to Heaven
}

\author{
Gregory Luke Chwala
}

Clemson University, South Carolina, USA

\begin{abstract}
This paper examines the ways in which Michelle Cliff's No Telephone to Heaven (1987) uses postcolonial Gothic conventions to articulate a convergence of gender, race, sexuality, capitalism, colonialism, and environment. I argue that the novel diverges from colonial values in its production of conflicting identity politics, and that these can be best understood through decolonial queer ecologies. The paper begins by situating the work of Omise'eke Natasha Tinsley and Edouard Glissant to lay a foundation for the decolonial queer ecocritical analysis that follows. Both Tinsley and Glissant stress the importance of the land to Caribbean culture and people, but Tinsley further establishes a framework for queer Caribbean studies that can help one better understand my critique of Cliff's No Telephone to Heaven. From this framework, I show how both raced and classed queer and trans characters transgress colonial boundaries through the ways that they reappropriate spaces and bodies in Jamaica's ruinate. I further examine how the Afro-Carib people who assemble in the ruinate challenge imperialism by forming a coalition that embraces trans leadership. In order to renegotiate human agency in the ruins of empire, Cliff's novel utilizes coalition building as a form of decolonization to explore nonhierarchical relationships between queer/non-queer characters and their relationship with the land. No Telephone to Heaven repurposes the Gothic as a means for characters to discover new, more productive relationships with one other and their environment.
\end{abstract}

Keywords: postcolonial Gothic, No Telephone to Heaven, decolonial queer ecologies 
This distinctive Jamaican term [ruinate] is used to describe lands which were once cleared for agricultural purposes and have now lapsed back into...'bush.' An impressive variety of herbaceous shrubs and woody types of vegetation appears in succession, becoming thicker and taller over the years until 'high ruinate' forest may emerge.... Ruinate of all forms is an all-too-frequent sign on the Jamaican landscape, despite population pressure on the land.

-Barry Floyd, Jamaica: An Island Microcosm (1979)

\section{Ruins of Empire: Decolonial Queer Ecologies in Cliff's No Telephone to Heaven}

7 he above epigraph which frames Michelle Cliff's novel No Telephone to Heaven (1987) provides foresight into a historical context that situates this essay. The ruinate that Cliff refers to applies not only to the reclamation of abandoned land by its vegetation, but is also a signification of reclaimed land by Jamaicans from British colonialists and American imperialists. Just as the colonizer consumes the resources of the land, so too does the ruinate consume the land; however, reclamation of Jamaican land by the ruinate acts as a trope that mirrors the reclamation of national identity from the ruins of empire. The ruinate is embraced by Cliff's characters as an adaptive agent that assists them with a rebellion to resist traces of British colonialism and continued American imperial exploitation. Escaped Afro-Carib slaves (the Maroons) had used the ruinate to hide, organize independent free communities, and assemble revolts when the British took possession of the island of Jamaica from Spanish colonists in 1655 (PortCities Bristol, n.d, para. 1). The ensuring conflict resulted in terrifying and brutal murder. The ruinate is thus a haunting cultural metaphor, part of a historical mental repository that draws attention to the importance of nature-culture interconnectivity in the process of Jamaica's decolonization. It is an allusion to what Lizabeth Paravisini-Gebert notes as the crossroads between the Caribbean colonial and the Gothic: "the frightful other, the defeated, the eerie, the disappeared, the dead" (2002, p. 254).

Paravisini-Gebert (2002) notes that late-twentieth century Caribbean women writers, like Cliff, continue a dialogue with the Gothic which begun with the prequel of Charlotte Brontë's Jane Eyre (1847), with Jean Rhys's Wide Sargasso Sea (1966). ParavisiniGebert explains how Clare Savage, the protagonist of No Telephone to Heaven, moves from "a quest for spiritual integrity into revolutionary martyrdom" (2002, p. 254). After reading Brontë's Jane Eyre, Clare Savage identifies with Bertha Mason (Rochester's Caribbean-born wife) over her impulse to resonate with Jane's plight, which is apparent when she states, "Yes, Bertha was closer to the mark. Captive. Ragout. Mixture. 
Confused. Jamaican. Caliban. Carib. Cannibal. Cimarron. All Bertha. All Clare" (Cliff, 1987 , p. 116). Paravisini-Gebert argues, "Clare's embracing of the marginal...is a powerful reminder of how the Gothic...has become a part of the language of the colonized, appropriated, reinvented, and in that way very much alive in worlds far beyond western Europe..." (2002, p. 254-255). Cliff's No Telephone to Heaven is quintessential postcolonial Gothic, a text that explores the postcolonial condition with Gothic tropes and eerie, haunting, historical, mental repositories. However, at the same time, it is rich environmental literature. It further deserves praise for its portrayal of non-binary gender and queer sexuality. It is a postcolonial Gothic text that offers material for a rich ecocritique and queer analysis.

This essay examines how values and attributes that define queer ecologies-coalitions, empathy, interdependency, biodiversity, and most importantly the ways that sexuality/gender and conceptions of nature inform one another-are present in No Telephone to Heaven. I trace what I call decolonial queer ecologies-reflections of the aforementioned queer ecological values and attributes which I claim assist in the process of decolonization-in order to investigate the ways in which Cliff uses Gothic terror and horror to depict queer characters and sublime landscapes in ways that enable Cliff and her characters to reverse and repair colonial damage to reclaim their agency and discover values displaced by colonialism. In sum, I argue that what makes Cliff's novel a decolonial text is its investment in queer ecologies. Queer ecologies are a necessary element in the production of decoloniality.

\section{Queer Ecologies as Decolonization}

No Telephone to Heaven shows the centrality of queer ecologies to a decolonial imaginary. Cliff uses Gothic tropes to describe postcolonial realities that highlight the Western-centrism of traditional realist/fantastic distinctions. In Cliff's novel, queer ecologies are grounded in materiality, for example, in the way that her characters use violent revolt to resist British colonialism and the recent American imperialism that has come to exploit their Jamaican land and culture. Decolonization, simply put, is the undoing of colonialism, but also a broader and deeper intellectual practice. I use the term as Walter Mignolo uses it to mean "delinking" from the "logic of coloniality" (2011, p. 143). Nevertheless, in decolonial novels, this often involves violence. As Frantz Fanon contends in The Wretched of the Earth, violence is often symptomatic of decolonization: "Decolonization is always a violent event" because "the colonist derives his validity, i.e., his wealth, from the colonial system" (1963. p. 1-2). Fanon asserts that all people are entitled to moral consideration - that no person is dispensable-but justice often requires 
dismantling and resisting constructions of the colonized world. This is the core of his decolonization theory which continues to inspire human rights and social justice, not unlike the goals of queer ecologies. However, this analogy is not the only relationship between these formations. Decolonization theory and queer ecologies notably share an urgency in deconstructing and dismantling human boundaries and obstacles that specifically exploit a separation of select human beings from their right to be a part of, and interact with, their environments-those deemed by colonialism to be not-quitehuman or nonhuman.

Michelle Cliff's novel showcases the relationship between queer ecologies and decoloniality. One cannot commit to decolonization without acknowledging queer ecologies because the ways in which the Western concept nature has influenced colonization is deeply ingrained in a discourse of sexuality and gender, and it is likewise impossible to have queer ecologies, even ecocriticism, without a commitment to decolonization because fear and oppression of Western conceptions of both the erotic and isolated nonhuman environments-erotophobia and ecophobia-are so deeply intertwined. "To queer" ecology means to scrutinize the intersections and boundaries of sexuality/gender and environment to understand the biosocial constitution of the material, nonhuman world, and our experiences and perceptions of what constitutes it. Catriona Mortimer-Sandilands and Bruce Erickson explain, "Queer, then, is both noun and verb in this project: ours is an ecology that may begin in the experiences and perceptions of nonheterosexual individuals and communities, but is even more importantly one that calls into question heteronormativity itself as part of its advocacy around issues of nature and environment-and vice versa" (2010, p. 5).

Queer ecologies offer a decolonial solution which can transform our understanding of how the material environment and culture inform one another in Cliff's novel as we explore the ways that characters come together and some reclaim their queer agency in ruinate to undermine hierarchies of race, gender, and sexuality. What is the significance of the diverse coalitions that are formed in the context of abandoned colonial land-now overgrown and reclaimed by its flora and fauna? On the one hand, Cliff comments on homophobia in her novel through the terror-stricken death of queer characters, but on the other hand, she also creates a safe environment for her trans character Harriet and her Afro-Carib revolutionaries in the ruinate of a once colonized land. Cliff's novel challenges colonialism through cultural reappropriation and the reclamation of ruinate. She positions the terror of revolutionary struggle alongside the transformation of her characters and landscape, both of which attempt to reclaim their agency, for the ruinate itself acts as a character of its own that haunts and resists colonial exploitation. 


\section{Reclaiming Ruinate}

In No Telephone to Heaven, characters of African descent are haunted by, but return to, nature to reclaim their agency in the ruins of empire. Cliff's fiction reveals how nature is an amalgamation that is informed by decolonialism through the ways that the human and the nonhuman are perceived. Her work deals with the ways in which the postcolonial subject is formed by British colonialism-but challenges it through queer ecologies. Ecologies become metaphors for subjectivities that move toward decolonization. Queer ecologies can be used to show how Michelle Cliff's Caribbean Gothic fiction overtly challenges colonialism and its relation to "nature" through the reappropriation of ruinate. In other words, a queer ecocritical analysis offers a means of decolonization in Cliff's No Telephone to Heaven.

The novel emphasizes the inseparability of Jamaican culture from its environment. In her retelling of Jamaican colonial history, Cliff stresses that Afro-Carib bodies have been marked and driven from Jamaican land that has been stolen, used, and afterwards abandoned. No Telephone to Heaven follows its protagonist, Clare Savage, through her travels in Jamaica, England, Europe, and the United States. Clare, a light-skinned Jamaican creole of English, African, and Arawak ancestry, immigrates to the U.S. from Jamaica with her family as a young girl, and after her parents' divorce, remains there with her father, while her mother and sister return to Jamaica. As a young adult, she studies in England but returns to Jamaica for vacations, where she befriends Harriet, a trans character. She eventually ends up in Jamaica, and with Harriet forms a guerilla revolutionary coalition that fights for the island's independence. The novel, written out of chronological order, begins and ends with the rebellion of the guerillas-in one scene preparing in the ruinate, and in the other, fighting an American film set in the Jamaican jungle-a landscape that becomes a character of its own.

Edouard Glissant argues in Caribbean Discourse (1999) that landscape often becomes a character in Caribbean writing: "The relationship with the land, one that is even more threatened because the community is alienated from that land, becomes so fundamental in this discourse that the landscape in the work stops being merely decorative or supportive and emerges as full character" (p. 105). Cliff utilizes the landscape as a character in her work to show the interconnectivity that Jamaicans come to experience with their land, a relationship that colonized peoples have typically been denied, despite the importance their ancestral cultures placed upon it. Land was especially important to Jamaican culture because of its ties to ancient African religions such as Obeah, Kumina, and Pocomania, each of which impress the importance of environment working in concert 
with organic life-the interconnectivity of ecosystems. Furthermore, the Taíno, an indigenous Arawak tribe with a matrilineal system of kinship, also practiced rich symbiosis with their environment. ${ }^{1}$ Though land once held great value to the natives of Jamaica, colonization robbed its people of much of their knowledge of, and respect for, the landalong with their human dignity. Caribbean writers of fiction remind readers of the importance of the land, often going to great lengths to characterize it, as part of a process of decolonization that might lead to a rediscovery and reclaiming of parts of those values that have been lost. Cliff attempts to repair these lost relationships with land in the ruins of empire. Reclaiming agency is a decolonial process that involves her characters rediscovering the ruinate.

Omise'eke Tinsley's Thiefing Sugar (2010) establishes the importance of ruinate in Cliff's novel by highlighting how nature is inseparable from the colonial histories that have altered and defined it; she argues that interior and exterior spaces are not so easily divided in the Caribbean, where "erotic geographies" underlie relationships that challenge norms formed during periods of great duress and oppression in opposition to slavery's stifling conditions. Tinsley furthermore asserts that understanding queer identities and relationships in the Caribbean is complicated because of Western-colonial, binary metaphors like "the closet" and "coming out"; metaphors which are problematic to an understanding of non-heteronormative relationships and identities in the Caribbean because they fail to consider the sociocultural importance of landscape and access to land $(2010$, p. 27$)$. These ideas are crucial for realizing the importance Cliff places in establishing healthier relationships between characters and Jamaican land in her novel.

Both human bodies and land are central to the anxieties of the Caribbean colonial imagination. Cliff takes up this problem of the inseparability of Jamaican people and land (or bodies and landscapes) in her novel, but she adds a further layer to this ecological critique that queers it. Several of her characters who have special connections with the land are first of all queered: Nanny of the Maroons, Harriet, and even Clare Savage herself. Secondly, the coalitions formed between queer and revolutionary characters often take place in the regrowth of ruinate. Thirdly, their reclamation of Jamaica from those Americans that they perceive to be exploiting their land and rewriting their history is an active form of decolonization that leads Cliff's characters to discover the importance of the queer bodies that inhabit Jamaica.

\footnotetext{
${ }^{1}$ For further study of the indigenous peoples of the Caribbean, see Nicholas J. Saunders's The Peoples of the Caribbean (2005). He provides a thorough background on the Taíno, Arawak, and African religious sects of Obeah, Kumina, and Pocomania. Saunders chronicles the struggle of indigenous people that are trying to reclaim and revitalize their cultural and historical identity.
} 
Conversely, Cliff's novel instills a sense of queer oppression that is understood to be a toxic byproduct of colonialism. There is a discourse surrounding the way that characters describe "battymen" (male homosexuals) as diseased, lesbian love as unfathomable, and gender transgressions as taboo. No Telephone to Heaven also draws attention to racial hierarchies that are reinforced in Jamaica through capital exploitation and economic class. Nevertheless, Cliff challenges the status quo with racial, gender, and sexual transgressions that are heavily vested in interdependency, a crucial aspect of queer ecologies that Catriona Mortimer-Sandilands and Bruce Erickson emphasise are vital for understanding the values shared by queer coalitions and biodiversity. This is witnessed through connections between oppressed people and land in Cliff's novel. Her characters cross boundaries, form bonds, and break down barriers to change the status quo, understand themselves, become something new, and create a place for themselves-a world pieced together from a cultural and historical mental repository of collected stories, knowledges, and a reconnection with the each other and the land.

Ancestral presence is experienced deeply when in the ruinate-a place where hierarchies seem to dissolve. Harriet, Cliff's trans character leading the revolution, discusses "de duppy" (spirits of the once enslaved Maroons) and their inseparability from naturemeaning the land. She tells Clare about what went on in the ruins of her grandmother's tropical land (once cane fields) and of its ghosts:

But I have seen them [their ancestors]...for I come here often.... Some of our people, girlfriend...some of our ancestors.... But, you know, t'ings not so different now. Do you know what happens on this island still? The lives of cutters, of timekeepers? ... Were we to sleep on this beach, we might hear more than...our people celebrating cropover. (1987, p. 131-32)

The insinuation is that by getting back in touch with the ruinate, Clare and Harriet are also rediscovering the culture of their once enslaved ancestors who fought for their freedom. This connection is further witnessed by a Gothic-like description of the ancestral ghosts that continues in "Magnanimous Warrior," a chapter consisting of only one page. The magnanimous warrior is described as "she whom the spirits come quick and hard. Hunting mother. She who forages. Who knows the ground" (1987, p. 163). She is described as caring for her people and scattering bone fragments among other natural debris (1987, p. 163) in an almost recursive recycling, but Cliff's hunting mother burns herself in an act of retaliation: "Mother who goes forth emitting flames from her eyes. Nose. Mouth. Ears. Vulva. Anus. She bites the evildoers that they become full of sores. She burns the canefields" (1987, p. 163-64). This magnanimous warrior which haunts and torments the living with fire is an ancestral spirit that is noticeably sexualized and gendered; yet, it 
furthermore alludes to a symbiosis with the land as an act of decolonial resistance. Harriet and Clare experience a sort of catharsis in the biosocial space they seek to reappropriate that helps them deal with the oppressive conditions their ancestors have been a part of, and of which they now face liberation from as queer individuals.

Clare and Harriet both strive for liberation from a restrictive colonial environment, a liberation found only in ruinate with each other. What is particularly striking about Harriet is that she redefines gender and opens up room for both the acceptance of nonconventional genders and a deconstruction of colonial logic, quite remarkable for a character in a novel written in 1987, when being queer or trans in Jamaica could mean death. Cliff was certainly embedded in feminist and queer contexts that suggest Jamaican homophobia did not go uncontested. However, Cliff characterizes Harriet's identity not as a singular phenomenon, but as a complex duality that is innately plural, and is manifested in her appearance. Sally O'Driscoll (1995) writes, "Cliff's project is to examine the possibility of claiming an identity - a project that moves her away from essentialist notions of identity and toward a postmodern concept of a constructed subject" (p. 61). Cliff's character Harriet is ahead of her time as a queer character in the 1980s whose identity is not stable but in flux; however, what is also interesting about Harriet is how her presence contributes to a deconstruction of the colonial system in No Telephone to Heaven.

\section{Reappropriating Spaces and Bodies}

Harriet is able to teach Clare a lot about her Jamaican identity, race, respect for the environment, and also gender and sexuality, which can be viewed as a challenge to the logic of the colonial system. However, it is the way that Harriet queers ecologies that makes her a unique character. Rosamond King (2008) argues that Harriet "re/present[s] the idea of gender itself by deconstructing the myth of the 'real woman' and the 'real man'" (p. 595). This is important because getting people to accept queer and trans individuals must start with a deconstruction of the problem. Harriet is able to teach both the limits of the colonial structures and that gender is not constrictive and limiting. She opens Clare to new possibilities and helps her to break down racial barriers as well as come to terms with her sexuality. Clare and Harriet are more similar than they would have thought; they are both talented leaders, largely because of what they learn from one another, and their plights are more similar than one first realizes. Though the role of a trans character opening up a cisgender character to new possibilities has been quite soundly critiqued in trans studies by scholars such as Jay Prosser (1998), what is unique about Harriet is the way that as a trans character, she challenges the colonial system and its overall structures through the ways she queers ecologies. 
Harriet introduces Clare to the complexity of identity and teaches her that queerness is not only legible as exclusive homosexuality. While Harriet's queerness as a trans person is more apparent to the revolutionaries than Clare's sexuality, Clare's queerness lies in her unique amalgamation-in her position of class-race-gender-sexuality and access to Jamaican environment. She appears to be heterosexual for the majority of the novel; an entire chapter is devoted to her relationship with an African-Vietnamese-American man, her pregnancy with his child, and subsequent miscarriage caused by what they assume to be his exposure to toxins during the war. The miscarriage leaves Clare sterile and, like Harriet, unable to reproduce as a woman. Yet, Harriet is able to give new meaning to gender, and she redefines what it means to be female in a profound way that transcends the idea that women hold a birthing role in reproduction, thus opening up possibilitiessuch as that of Clare and Harriet's love affair. However, Clare's queerness lies not only in her same-sex experiences with Harriet, but also in her challenge to heteronormative roles: in reproduction and maternity, in a love affair with a trans character, and in her ability to see Jamaica from a unique perspective as a creole woman who has been able to migrate across continents. She and Harriet are maternal to their cause, to the revolutionaries, and to Jamaica, but Clare's queerness puts her in the unique position of giving Harriet the ability to seek decoloniality.

Clare and Harriet's ability to decolonize, however, is importantly first grounded in queer ecologies, largely through the way that they are able to reappropriate not only their bodies, but also spaces. This is evidenced in a scene in where Harriet and Clare go swimming on the "most beautiful beach on the island" (1987, p. 130) of Jamaica, the most secluded, where "they could swim as girlfriends" (1987, p. 130). They frolic and eat mangos, then lie side by side, "touching gently, kissing, tongues entwined, coming to, laughing" (1987, p. 130). When Harriet asks Clare if she finds her strange, although Clare responds that she finds Harriet no stranger than she finds herself, Clare expresses: "Of course, I find you strange; how could I not? You are a new person to me. At the same time I feel drawn to you. At home with you," to which Harriet responds, "The time will come for both of us to choose. For we will have to make the choice. Cast our lot. Cyann [can't] live split. Not in this world" (1987, p. 131). In the Jamaican wilderness, Clare feels comfortable with her queerness, yet Harriet senses Clare's dilemma in having to choose between a heteronormative and queer orientation. The sense is that the remote landscape is what offers them a life free from colonial restriction, and Harriet emphasizes the importance of choosing what feels natural.

Even though Clare feels drawn to and at home with Harriet, Harriet's statement regarding having to make a choice presents a contradiction. Omise'eke Natasha Tinsley calls this 
scene the "novel's most erotic and postcolonial journey" (2010, p. 188), refers to Harriet's agency as "male womanhood" (2010, p. 169), and Harriet's and Clare's relationship as "lesbian eroticism" (2010, p. 192). Harriet's "choice" might not be as straightforward as it seems. The choice might lie in a blurring of distinctions-in choosing between living in the ruins of empire, versus moving toward becoming something new and building a different future. Furthermore, the choice to which Harriet refers can be understood as queering the permanence of gender and sexuality altogether-in seeing the environment in all its complexity as a movement toward decolonization. Tinsley writes, "This secluded afternoon is a moment when s/he [Harriet] makes an intimate connection to one Jamaican whom s/he can love and help lead to freedom while embracing both woman's full complexity, and so opens the novel's only lesbian love scene and a unique imagination of the erotics of decolonizing gender and sexuality otherwise" (2010, p. 192). Tinsley's close reading attests to the importance of reappropriating (queer) spaces and bodies as a means of decolonization; Harriet and Clare's erotic encounter with one another acts as a form of colonial resistance deeply entwined with the land that in turn propels them to form a coalition with guerilla revolutionaries.

\section{Queer Coalitions}

Omise'eke Natasha Tinsley (2010) draws attention to queer coalitions formed between women who loved women in Caribbean history, from middle-passage same-sex eroticism to same-sex relationships that were part of a rebellion under brutal conditions of slavery. She also draws attention to the importance of coalitions between Caribbean revolutionaries and nature (p. 1-28). Tinsley examines metaphors of landscape and sexuality which undermine an "imperial obsession with separation and categorization that divides human from slave, female from woman, and man from nature," metaphors which instead emphasize connectivity and form what she calls a "poetics of erotic decolonization" (2010, p. 23). Nature, when understood through a decolonial context in the Caribbean, she argues, is not static nor distanced from human culture, but importantly interconnected to an understanding of queer agency. "Flowers, trees, land forms, sexed bodies, sexual natures," she notes, have been "constantly, tactically remade by both colonialists and countercolonialists" (2010, p. 22), never static, but always in a state of interruption, redirection, and bonding. These interconnections (these coalitions) are crucial to an understanding of queer ecologies, and not just true of the Caribbean. Mortimer-Sandilands and Erickson further argue that "a queer ecological framework not only... offer[s] a possibility of coalitions between racial and sexual inequities, but also would necessarily provide an analysis of the contemporaneous development of race, sexuality, and nature through each other" $(2010$, p. 35$)$. This redirection is, at times, an 
important aspect of rebellion and revolution led by characters who refuse to conform to sexual, gender, and racial normalities.

Tinsley's argument helps to not only situate the importance of environment in Caribbean culture, but also enables readers to see the value of rebellions and revolutions that emphasize the importance of wilderness spaces to the process of decolonization; resistances which are instrumentally dependent on queer coalitions. This discussion leads to one final application of decolonial queer ecologies to Cliff's No Telephone to Heaven - the emphasis that heterogeneous coalitions which celebrate naturecultures can establish needed solutions. Katie Hogan, in her article "Coalition Building as Queer Environmentalism" (2010), reminds us that coalition is an important aspect of queer ecologies. Although Hogan has written for a contemporary U.S. audience, her overall argument is also useful in a decolonial context. She claims that who is deemed natural and has access to nature, has historically depended on a person's race-gender-sexualityclass, noting how people of color and queer people have been driven from nature and/or had unsafe access to it because they are deemed unnatural $(2010, p .241)$. This is not unlike what happened in postcolonial Jamaica. Hogan argues that queers and minorities must reclaim naturecultures through coalition building (2010, p. 236-41). She writes:

Since both queer and environmental justice perspectives assume that nature and environment are not neutral ahistorical categories, and each critical practice looks at how the very language of nature and environmentalism can often mask harm to humans and nature, this shared theoretical and historical experience could serve as a basis for coalition. (2010, p. 241)

Queer coalition building stresses that people should not be alienated nor marginalized from the land and emphasizes the interdependency of Earth's biodiversity to maintain a healthy world. It is not queerness that is unnatural or threatening, but rather economic imperialism and homophobia that are toxic. Coalitions that consist of queer and non-queer characters interacting with the land are instrumental stories in No Telephone to Heaven.

Clare and Harriet decide to fight back by forming a coalition. They and their revolutionaries train within the grounds of her deceased grandmother's ruinate, where Clare expresses an anger regarding the toxic pollution of their ancestral land and water as a result of colonization, a damaged past they seek to avenge as a way of moving forward into the future. It is important to note that although Clare's inheritance from a colonizer is what provides this land for their coalition, it is not simply her position alone that enables this coalition, but the process of discovering connections between the land and queerness 
that have enabled a decolonial resistance to form. Clare says, "You know then that the rivers run red... and the underground aquifers are colored...from the waste of the bauxite mines and the aluminum refineries? We do not speak of past here, but present, future" (1987, p. 195). This passage is important for two reasons. First, it highlights the relationships among industry, colonialism, and ruinate to show the ways that the land cannot be fully taken back-how colonialism endures in the form of poisons. Second, the future Clare speaks of is grounded in a decolonization invested in queer coalition, queer becoming, queer temporalities, and queer ecologies. Though the land cannot be fully reclaimed, relationships with the land can change for the better. This is one way that No Telephone to Heaven invests in queer ecologies as a movement toward decolonization.

Harriet also resists colonialism and embraces queer ecologies on many fronts to promote change and build queer coalitions. As noted, she insists that her gender and sexual identity are a product of nature, a term she transforms and redefines as a process of becoming, rather than a cultural product of male-on-male rape and white colonialism, for instance. She also sees no reason for changing her biological body, which is arguably another act of colonial resistance and her choice, despite whether or not she could afford trans reassignment surgery: "Cyann [can't] afford [genital reconstruction]," Harriet tells Clare, "Maybe when de revolution come . . . but the choice is mine, man, is made. Harriet live and Harry be no more...you know, darling, castration ain't de main t'ing" (1987, p. 168). Harriet's refusal of trans reassignment surgery is importantly embraced by the coalition of guerilla revolutionaries she leads, who recognize Harriet as female, yet are indifferent to her remaining biologically male. Thus, both her decision, and the revolutionaries' embracement of her trans identity, can be construed as an anti-colonial move that allows her to be queer and accepted, and allows the revolutionaries to defy the gender and sexual normativity they have inherited from a colonial legacy-which strengthens their coalition. Furthermore, Harriet's independence and queer leadership reflects Jamaica's self-sufficient ability: "The trans body, like Jamaica, is presented as independent and self-sufficient: close to nature in an ideal sense, rather than underdeveloped, primitive, and in need of outside help. In fact," Seymour writes, "the novel [No Telephone to Heaven] nearly collapses organic transgenderism and anticolonial militance into each other" (2013, p. 60). An independent Jamaica that is interdependent with queer and non-queer bodies alike as well as cognizant of the role of nature (to use Seymour's word) in its future is the goal of this coalition.

Harriet's revolution wants to be independent from American imperialism, including capital and tourism, and the revolutionaries plan to invade an American movie set that has come to exploit Jamaica and rewrite the history of its legendary hero, Nanny of the Maroons. It 
is important to realize that their goal is not economically motivated, but an anti-colonial quest to fight segregation and economic inequality with the aim of taking back ownership of their cultural heritage from the colonial development of Jamaica. Seymour clarifies the intent of the guerilla revolutionaries when she writes, "Cliff makes clear that this band is changing the landscape not for profit through exploitation, but as a way to repair that exploitation. And, interestingly enough, they leave a layer of ruinate to keep their operations under cover-a human-nonhuman reciprocity that is engineered, but reciprocal nonetheless" (2013, p. 60). This point is important not only because it emphasizes the unselfish motives of the coalition, but also because it highlights the reciprocal relationship they have built with their environment.

Cliff's coalition reinvests in a knowledge and rediscovery of nature/culture interdependence that values queer bodies and spaces, and its members resist being othered or viewed as monstrous rebels or terrorists-instead using terror themselves to reclaim their land and culture from American imperialists. What is also interesting is the way that the ruinate is used as a place to form a coalition between oppressed Others that society considers misfits; the ruinate becomes a place wherein the guerilla revolutionaries can reclaim the land not for capital profit or exploitation, but as a way to repair the colonial damage that has been done. However, there is no easy way out of the colonial matrix; the revolutionaries also strategically embrace capital when they need to in order to achieve their goals, as they do in the case of Clare's relation of ownership to the land. Decolonization is a process-not a straightforward, easy solution. The point is that this coalition emphasizes an important attribute of decolonial queer ecologies-natural space becomes queer cultural space. The characters of Cliff's decolonial fiction realize that the commodification of the environment as well as hierarchical cultures-both understood as products of colonialism - cause imbalance in their world. They discover spaces that welcome queer bodies and explore a means of decolonization through coalitions that are both queer-inclusive and ecofriendly.

Decolonizing Jamaica materializes for the revolutionaries in a united purpose and common goal to expel American filmmakers from Jamaica who are trying to rewrite their history-the history of their heroine, Nanny of the Maroons. As noted, it is equally important to remember that their union is organized and led by the trans character Harriet, with whom Clare and the revolutionaries empathize and welcome, now seemingly only within the confines of the ruinate in which they meet; Harriet is only allowed to be queer and unrestrained in the ruinate (1987, p. 130-31). Harriet's freedom becomes Jamaica's freedom. As Seymour writes, "Gender freedom and freedom from colonial domination thus become inseparable goals" (2010, p. 60), but freedom in the ruinate becomes their 
means and cause. In this ruinate, they plant and garden for sustainability (yam, cassava, plantain, coconuts, and apples), but they also leave much of the ruinate wild for their protection from authorities. Thus, they work with the land, protect it from exploitation, and receive their nourishment from it-a reciprocal relation. The coalition is able to transgress terror and rediscover a symbiotic relationship with their environment, and even though the rebellion is unsuccessful, there is a promise of success in their failure through their union with one another in and with the ruinate, and in the novel's queer ecological temporalities.

A queer ecological temporality surfaces in Cliff's work, for example, by the way she refuses to allow her story to be defined by its ending. The revolution is not defined by its failure, but instead challenges readers to think about how queer failure offers new alternative possibilities. Jack Halberstam argues in The Queer Art of Failure that "under certain circumstances failing, losing, forgetting, unmaking, undoing, unbecoming, not knowing may in fact offer more creative, more cooperative, more surprising ways of being in the world" (2011, p. 2-3). I posit that No Telephone to Heaven's indeterminate ending does these things.

The language used on the last page (and in the last two chapters) of Cliff's novel suggests a queer non-lineal, temporality. It ends with onomatopoeia and shots fired, framed between the words: "She remembered language. Then...it was gone" and the novel's last two words, "Day broke" (1987, p. 208). Cliff's use of language in her last two chapters explores history as queer loss and memory, evoking yet another queer temporality. In the chapter entitled, "The Great Beast," Cliff explores hybridity and a queer rewriting of history: "This new sort of history...that you have taken on; is there proof involved in it as well," Clare is asked (1987, p. 194). She replies: "It's not as simple as that. I am in it. It involves me [. . ] the practice of rubbing lime and salt in the backs of whipped slaves [. . .] the ambush tactics of Cudjoe [. . . ] the promised fight of Alexander Bedward in rapture back to Africa [ . . ] cruelty [ . . .] resistance [ . . ] grace. I'm not outside this history-it's a matter of recognition [. . .] memory [. . .] emotion" (1987, p. 194). Clare negotiates her history and finds herself implicated in the actions of the colonizer. She finds herself caught up in a colonial system that is difficult to release entirely, but, in feeling backwards, she comes to understand history through place-with the land. She says, "I have walked the cane [ . . . ] poked through the ruins [. . .] rusted machines marked Glasgow [. . .] standing as they were left. I have swum underwater off the cays.... Yes-some history is only underwater" (1987, p. 193). 
Readers might view Clare's introspection (as well as the novel's indeterminate ending) as transformational rather than failure. Decolonization is about struggle, and the work is never quite finished. Decolonial queer world building is not an end, but a process always being remade. Cliff's writing is successful because the goal of her work is to recognize the complexity and contradiction that colonization and life after colonization always involves. For Clare, unbecoming who she is works to undo and unmake her inheritance of colonialism and plot new directions-to rediscover alternative, new natures.

\section{Transgressing Terror, Rediscovering Natures}

Michelle Cliff provides hope for transgressing the realities (the terrors) of postcolonialism through her protagonist Clare Savage, who rediscovers the value of interdependency between nature/culture to include queer individuals and coalitions that invest in more sustainable, ecological practices. Cliff seems to insinuate that the rediscovery of an ancestry and culture before the British colonization of Jamaica can help solve some of the problems which have separated people from their environments and created hierarchies of race, gender, class, and sexuality. Queer ecological values are realized and practiced by Cliff's protagonist and revolutionary characters as they work to decolonize Jamaica from both a history of British colonization and new looming threats of American imperialism. Cliff shows that through decolonial queer ecologies individuals can divest themselves of colonial baggage to re-inherit a tradition that understands a world beyond binary gender roles and sexual orientations, a world in which interdependency is necessary and urgent. She shows that through decolonial queer ecologies, characters transgress traditional Gothic themes and tropes in decolonial literature that have served as methods of regulation to reproduce Eurocentric conceptions of a racialized Other as well as possess ownership of land. It is the rediscovery and redefining of nature that moves these transgressions.

Cliff's postcolonial Gothic fiction shows a growing awareness of the ways that colonialism has created hierarchies of power based on the biological determinism of human bodies and environments, and it works to undo them. No Telephone to Heaven deconstructs colonialism, rather than negotiating it alone. For Cliff, Gothic tropes are used to describe postcolonial grim realities still facing much of the Caribbean: neoliberalism, homophobia/xenophobia, and environmental turmoil-problems rooted in postcolonialism and modern-day imperialism (in the ruins of empire). No Telephone to Heaven explores human and non-human ecologies to engage the imagination in queer ways of being, becoming, and understanding. These alternatives offer a reparative reading strategy for decolonization that is firmly rooted in queering Jamaican ecologies. 


\section{References}

Cliff, M. (1987). No telephone to heaven. New York, NY: E.P. Dutton.

Fanon, F. (1963). The wretched of the earth. (R. Philcox, Trans). New York, NY: Grove Press.

Glissant, E. (1999). Caribbean discourse: Collected essays. (J. M. Dash, Trans). Charlottesville, VA: University of Virginia Press.

Halberstam, J. (2011). The queer art of failure. Durham, NC and London, UK: Duke University Press.

Hogan, K. (2010). Undoing nature: Coalition building as queer environmentalism. In C. Mortimer-Sandilands \& B. Erickson (Eds.), Queer ecologies: Sex, nature, politics, desire (pp. 231-253). Bloomington, IN: Indiana University Press.

King, R. (2008). Re/Presenting self and other: Trans deliverance in Caribbean texts. Callalloo, 31(2), 581-599. doi:10.1353/cal.0.0085

PortCities Bristol. (n.d.). The maroons of Jamaica. Retrieved from http://discoveringbristol.org.uk/slavery/against-slavery/black-resistance-againstslavery/the-maroons-of-jamaica/

Mignolo, W. D. (2011). The darker side of western modernity: Global futures, decolonial options. Durham, NC, and London, UK: Duke University Press.

Mortimer-Sandilands, C. \& Erickson, B. (Eds.) (2010). Queer ecologies: Sex, nature, politics, desire. Bloomington, IN: Indiana University Press.

O'Driscoll, S. (1995). Michelle Cliff and the authority of identity. The Journal of the Midwest Modern Language Association, 28(1), 56-70. doi:10.2307/1315243

Paravisini-Gebert, L. (2002). Colonial and postcolonial Gothic: the Caribbean. In J. E. Hogle (Ed.), Cambridge Companion to Gothic Fiction (pp. 229-257). Cambridge, UK: Cambridge University Press.

Prosser, J. (1998). Second skins: The body narratives of transsexuality. New York, NY: Columbia University Press.

Saunders, N. J. (2005). The peoples of the Caribbean: An encyclopedia of archeology and traditional culture. Santa Barbara, CA, Denver, CO, and Oxford, UK: ABCCLIO.

Seymour, N. (2013). Strange natures: Futurity, empathy, and the queer ecological imagination. Urbana, Chicago, and Springfield, IL: University of Illinois Press.

Tinsley, O. N. (2010). Thiefing sugar: Eroticism between women in Caribbean literature. Durham, NC and London, UK: Duke University Press. 